\title{
Thermogenesis in four species of Schismatoglottis Calyptrata Clade (Schismatoglottideae: Araceae)
}

\author{
Yin Chen Hoe ${ }^{1}$ (D), Marc Gibernau², Sin Yeng Wong ${ }^{3,4}$ \\ ${ }^{1}$ Tunku Abdul Rahman University College, Johor Branch Campus, Segamat, Malaysia \\ ${ }^{2}$ CNRS - University of Corsica, UMR 6134 - SPE, Natural Resources Project, Vignola Route des Sanguinaires, Ajaccio, \\ F-20000, France \\ ${ }^{3}$ Institute of Biodiversity and Environmental Conservation, Universiti Malaysia Sarawak, Samarahan, Sarawak, 94300, \\ Malaysia \\ ${ }^{4}$ Research Associate, Harvard University Herbaria, 22 Divinity Avenue, Cambridge, MA, 02138, USA
}

Spadix temperature was measured in Schismatoglottis ahmadii, S. lowiae, S. sp. nov., and S. wallichii. The anthesis of $S$. lowiae, S. sp. nov., and $S$. wallichii started just after dawn but in $S$. ahmadii, it began two hours later. Spadix temperatures of the four species increased at the beginning of each of the two successive flowering mornings, corresponding respectively to the pistillate and staminate phases of anthesis. The appendices of $S$. ahmadii, S. lowiae, and $S$. sp. nov. underwent the highest temperature increases (average $9.5^{\circ} \mathrm{C}$ above ambient air) compared to the staminate zone $\left(6.5^{\circ} \mathrm{C}\right.$ above ambient air); almost no thermogenic activity was recorded in the pistillate zone $\left(0.4^{\circ} \mathrm{C}\right.$ above ambient air). In inflorescences of $S$. wallichii, in which the spadix lacks an appendix, the pistillate zone also heated up $\left(2.3^{\circ} \mathrm{C}\right.$ above ambient air), together with the sterile $\left(2.6^{\circ} \mathrm{C}\right.$ above ambient air) and the staminate zones $\left(5.2^{\circ} \mathrm{C}\right.$ above ambient air). Thermogenic patterns varied across species owing to differences in timing of anthesis or spadix structures. The absence of an appendix (sterile floral tissue) in $S$. wallichii, is not only partially compensated by heat production from the (intermediate) sterile zone but also heat production from the pistillate zone, recorded here for the first time in Tribe Schismatoglottideae.

\section{Keywords:}

Borneo, heating flower, inflorescence, spadix zonation, size correlation
Submitted: June 6, 2020

Revised: September 29, 2020

Accepted: October 25, 2020

\section{Introduction}

The genus Schismatoglottis Zoll. \& Moritzi comprises ca 120 described species (Boyce \& Croat 2020). The majority of the genus diversity occurs in Malesia and particularly on Borneo (Hay \& Yuzammi 2000, Wong 2013). Within Schismatoglottis, the Calyptrata Clade sensu Low et al. (2018) is defined by mostly colonial stoloniferous herbs with hapaxanthic stems, a persistent petiolar sheath and ovato-sagittate to oblong-lanceolate blades. Inflorescences are produced sequentially in a synflorescence, typically up to eight, occasionally more,

\section{Correspondence}

Hoe Yin Chen, Tunku Abdul Rahman University College, Johor Branch Campus, Malaysia.

Email: ravichoe@yahoo.com seldom solitary. Each inflorescence is composed of an hour-glass-shaped spadix subtended by a spathe, the last modified leaf of the flowering article. The spathe is divided into a lower part (the tube) and an upper part (the blade) separated by a pronounced constriction coinciding with the intermediate sterile zone of the spadix. The spathe blade falls off at the onset of staminate anthesis, with only the lower spathe tube remaining to protect the female flowers. The spadix is divided into four floral zones, from the base upwards: pistillate zone, sterile zone, staminate zone, and a sterile appendix (not always present). The pistillate flowers are irregularly associated with clavate interpistillar staminodes. Each staminate flower is mostly composed of two, rarely three or four, stamens. The inflorescence is protogynous and releases a strong esteric odour during anthesis (Hoe et al. 2018, Wong et al. 2016). The clade comprises 73 